\title{
Bone Radiography
}

National Cancer Institute

\section{Source}

National Cancer Institute. Bone Radiography. NCI Thesaurus. Code C137876.

Radiographic imaging of bone. 